\section{Fish community response to evolving channel complexity in an agricultural headwater system}

\author{
T.D. Crail, J.F. Gottgens, and A.E. Krause
}

\begin{abstract}
Headwaters in many watersheds in the midwestern United States are often dominated by ditches that are dredged to drain farmland and are maintained as homogeneous channels. These ditches may provide important headwater habitat for fish but are rarely managed as such. With reduced dredging, these ditches tend to stabilize their cross-sectional profile with patchy sediment deposits and plant growth. We tested the impact of such channel complexity on the structure of fish communities in agricultural ditches of the upper Ottawa River (Ohio), a western Lake Erie tributary, by comparing twelve $20 \mathrm{~m}$ (66 ft) channel segments with and without such complexity (heterogeneous [Ht] and homogeneous [Ho] respectively). Fish communities were sampled at low water with block seines in each site eleven times between June 2005 and October 2006. Temperature, pH, turbidity, dissolved oxygen, conductivity, and discharge were comparable between $\mathrm{Ht}$ and Ho segments during each sampling event. A total of 10,843 fish representing 24 species were identified, assessed for spawning condition and age class, and released. In spite of the large variability in fish community metrics over time, $\mathrm{Ht}$ habitat had a higher species richness $(\mathrm{Ht}=6.56 \pm 0.63, \mathrm{Ho}=$ $4.17 \pm 0.63 ; p=0.02)$, Shannon diversity $(\mathrm{Ht}=1.33 \pm 0.12, \mathrm{Ho}=0.90 \pm 0.12 ; p=0.03)$, and number of feeding guilds $(\mathrm{Ht}=3.2 \pm 0.20, \mathrm{Ho}=2.2 \pm 0.20 ; p=0.01)$. Fish abundance and Index of Biotic Integrity showed no significant effect for habitat. The community was dominated by tolerant cyprinids (Pimephales promelas and P. notatus) but also contained 1,514 Etheostoma microperca, a previously undocumented population and species listed as a "State Species of Concern" in Ohio. The majority (73\%) of E. microperca were found in Ht segments In spite of the prevalence of exotic species in other regional aquatic systems, only $0.7 \%$ of the total catch belonged to nonnative species. With the majority of headwaters in the midwestern United States consisting of dredged ditches, balancing management for efficient drainage while allowing some level of channel complexity may benefit native fishes and contribute to surprisingly rich communities.
\end{abstract}

Key words: agricultural ditches-channelized streams-fish communities-habitat heterogeneity-vegetated benches

\begin{abstract}
Many drainage districts in the midwestern United States begin in human-created waterways or in natural waterways that have been channelized. These humanmaintained headwater streams, known as agricultural "ditches," are designed to remove excess surface water to improve agricultural yields (Smiley et al. 2008). Given the perceived homogeneity of such habitat and the ephemeral nature of water in these ditched waterways, it is generally assumed by farmer and scientist alike that these systems support a severely impoverished aquatic commu-
\end{abstract}

ness during heavy discharges (Ward and Trimble 2004). Unless disturbed by dredging, these channels will respond over time by stabilizing their cross-sectional profile with sediment deposits and plant growth (Lyons et al. 2000; Rhoads et al. 2003), creating patches of narrower and deeper habitat that alternate with wider and shallower stream sections. Advances in soil conservation, perhaps coupled with a reduced need for dredging, have contributed to research and applications for managing these waterways both as stream habitat and drainage ditches using compound channels with such "vegetated benches" (Frothingham et al. 2002; Landwehr and Rhoads 2003; Ward and Trimble 2004; Boody et al. 2005). Here, we test the response of fish assemblages to early morphological stream habitat development (i.e., naturally formed vegetated benches) in the headwaters of the Ottawa River, a western Lake Erie tributary in northwest Ohio, United States. The upper Ottawa (known as Tenmile Creek) is dominated by agriculture and is methodically maintained in a channelized form to promote drainage by periodic dredging with heavy machinery to remove sediment and vegetated benches. While such routine dredging indicates sedimentation from erosion from adjacent fields and channel banks, our focus was not in these sedimentary processes. Rather, we concentrated on quantifying the response of the fish community to changes in these processes.

Based on survey work conducted from 2002 to 2004, we found that these ditches provided habitat for a remarkable fish community in spite of the frequent and repeated disturbance from sediment removal. For example, in Langenderfer and Prairie ditches, both constructed tributary waterways in the Tenmile Creek watershed (figure 1), we found 23 native species of fish representing seven families and a near absence of exotic species. We noted that certain stream segments seemed to host a richer and more abundant assemblage of fishes than other segments. Specifically, a more species-rich community seemed to coincide with geomorphologically heterogeneous segments characterized by vegetated benches, in con-

Todd Crail is a doctoral student, Hans Gottgens is a professor, and Ann Krause is an assistant professor in the Department of Environmental Sciences at the University of Toledo, Ohio, United States. 


\section{Figure 1}

The Ottawa River watershed location with aspect to North America and field sites in the Ottawa River watershed, northwest Ohio. Odd numbered sites represent heterogeneous $(\mathrm{Ht})$ segments; even numbered are homogeneous (Ho) sites. All segments were interspersed minimally $50 \mathrm{~m}$ apart, and all sampling occurred from the farthest downstream to the farthest upstream to leave each new segment undisturbed.

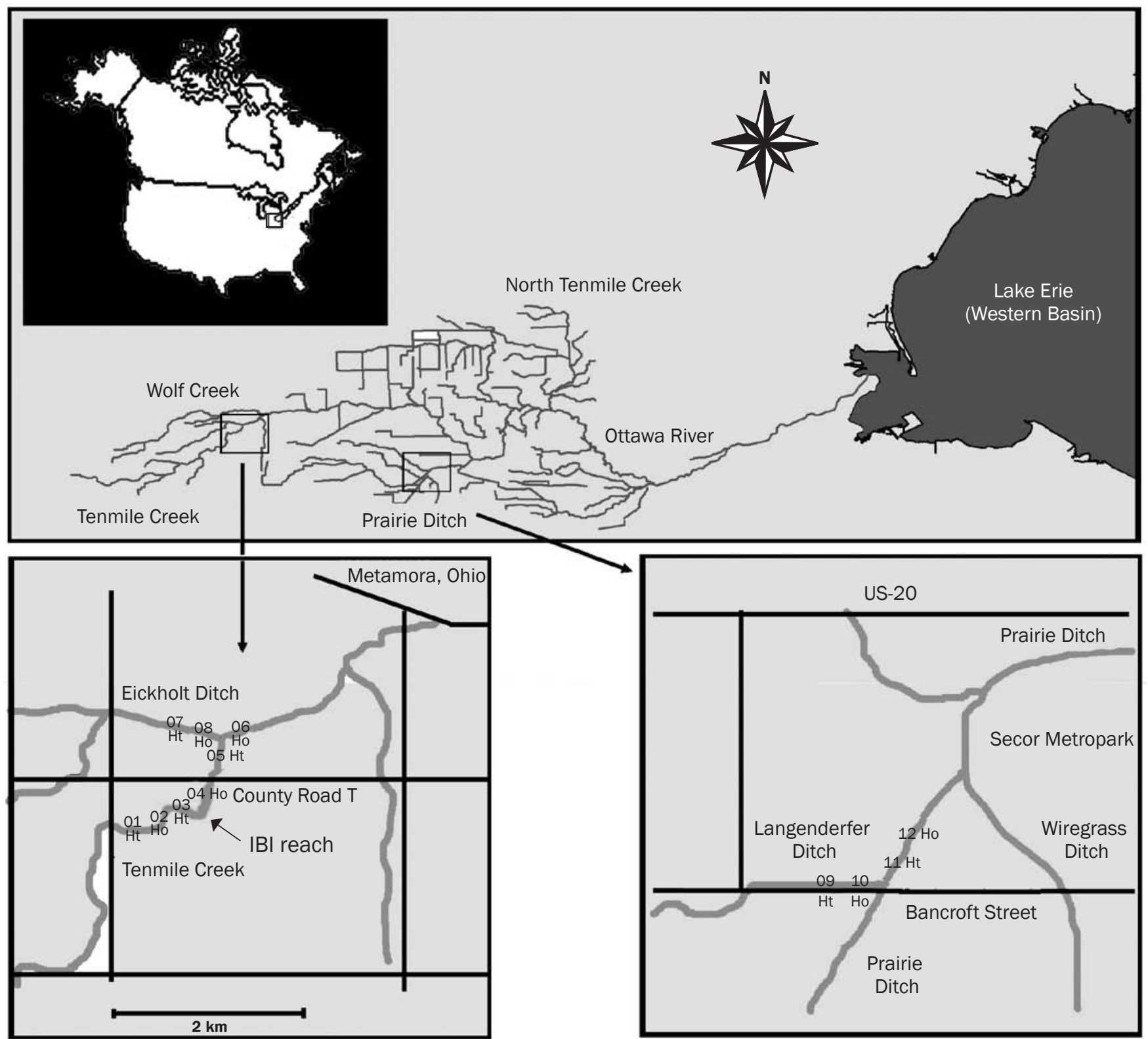

trast to homogeneous segments that lacked bench development since the last channel clean-out. These benches were mainly formed by the dominant stream bank plant, reed canary grass (Phalaris arundinacea L.). This tolerant grass is commonly found in wet habitat surrounding degraded areas interspersed with a mix of native emergent and wholly aquatic plants occurring in lower frequency. Our preliminary observations provided the impetus for a quantitative test of the response of the fish community to early, passive channel development by comparing structurally heterogeneous segments with homogeneous segments.

We selected two different stream habitat types as end points in this channel development: heterogeneous (Ht or "benched") and homogeneous (Ho or "benchless"). We hypothesized that the fish assemblage in $\mathrm{Ht}$ habitat would have a significantly higher abundance per species, richness, Shannon diversity $\left(\mathrm{H}^{\prime}\right)$, number of feeding guilds, and Index of Biological Integrity (IBI) (Karr 1981) than the fish assemblage in Ho habitat. As such, we intended to contribute both to basic understanding (e.g., how important is geomorphic complexity as an influence on headwater stream fish communities) and to management (e.g., would balancing management for efficient drainage while allowing for some level of channel complexity benefit native fishes). 


\section{Table 1}

Mean channel width (in $\mathrm{cm}, n=11$ ), center depth (in $\mathrm{cm}, n=18$ ) with corresponding standard deviation and coefficient of variation for twelve $20 \mathrm{~m}$ $(66 \mathrm{ft})$ sites in the Ottawa River watershed, northwest Ohio. Channel widths were measured as the wetted width every two $2 \mathrm{~m}(6.6 \mathrm{ft})$ along each segment. Channel depth was measured at the channel midpoint and half way between the midpoint and each bank at every $4 \mathrm{~m}$ ( $13.2 \mathrm{ft}$ ) along each $20 \mathrm{~m}$ (66 ft) segment. Sites with odd numbers were structurally heterogeneous ( $\mathrm{Ht}$ ); sites with even numbers were structurally homogenous (Ho).

\begin{tabular}{|c|c|c|c|c|c|c|c|c|c|c|c|c|}
\hline \multirow[b]{2}{*}{ Statistic } & \multicolumn{12}{|l|}{ Site } \\
\hline & $\begin{array}{l}\text { Tenmile } \\
01 \mathrm{Ht}\end{array}$ & $\begin{array}{l}\text { Tenmile } \\
02 \text { Ho }\end{array}$ & $\begin{array}{l}\text { Tenmile } \\
\mathbf{0 3 ~ H t}\end{array}$ & $\begin{array}{l}\text { Tenmile } \\
04 \text { Ho }\end{array}$ & $\begin{array}{l}\text { Tenmile } \\
05 \mathrm{Ht}\end{array}$ & $\begin{array}{l}\text { Tenmile } \\
06 \mathrm{Ho}\end{array}$ & $\begin{array}{l}\text { Eicholt } \\
07 \mathrm{Ht}\end{array}$ & $\begin{array}{l}\text { Eicholt } \\
08 \mathrm{Ho}\end{array}$ & $\begin{array}{l}\text { Lang } \\
09 \mathrm{Ht}\end{array}$ & $\begin{array}{l}\text { Lang } \\
10 \mathrm{Ho}\end{array}$ & $\begin{array}{l}\text { Prairie } \\
11 \mathrm{Ht}\end{array}$ & $\begin{array}{l}\text { Prairie } \\
12 \text { Ho }\end{array}$ \\
\hline Mean & 232.1 & 280.8 & 229.1 & 382.7 & 234.5 & 299.7 & 151.5 & 130.5 & 168.7 & 273.8 & 251.2 & 303.1 \\
\hline sd & 46.6 & 18.1 & 51.1 & 13.5 & 43.4 & 23.2 & 54.7 & 20.4 & 27.5 & 21.5 & 42.6 & 18.2 \\
\hline $\mathrm{CV}$ & 0.20 & 0.06 & 0.22 & 0.04 & 0.19 & 0.08 & 0.36 & 0.16 & 0.16 & 0.08 & 0.17 & 0.06 \\
\hline Mean & 26.3 & 21.2 & 22.4 & 15.2 & 22.0 & 18.9 & 26.3 & 28.4 & 26.3 & 27.0 & 39.3 & 27.7 \\
\hline $\mathrm{sd}$ & 6.1 & 3.1 & 8.0 & 5.1 & 4.8 & 5.9 & 9.1 & 7.0 & 8.5 & 8.1 & 5.7 & 3.6 \\
\hline CV & 0.23 & 0.15 & 0.36 & 0.33 & 0.22 & 0.31 & 0.35 & 0.25 & 0.32 & 0.30 & 0.14 & 0.13 \\
\hline
\end{tabular}

Notes: $\mathrm{sd}=$ standard deviation. $\mathrm{CV}=$ coefficient of variation.

\section{Materials and Methods}

Location. Twelve $20 \mathrm{~m}$ (66 ft) stream segments were selected in the headwaters of the Ottawa River (figure 1), a western Lake Erie tributary in a $446 \mathrm{~km}^{2}\left(172 \mathrm{mi}^{2}\right)$ watershed in northwestern Ohio, United States (Benedict and Gottgens 2006). The Ottawa River is a low-gradient $\left(10.4 \mathrm{~m} \mathrm{~km}^{-1}[55 \mathrm{ft}\right.$ $\mathrm{mi}^{-1}$ ]) catchment consisting of agricultural, suburban, and urban environments (Roberts et al. 2007) and is a part of the Maumee River Area of Concern (USEPA 2009). The selected segments were on second order streams in Fulton and Lucas counties flowing into Tenmile Creek, which becomes the Ottawa River (figure 1). All segments were within catchments of intense agricultural land use dominated by row cropping of corn and soybeans, which was also the land use adjacent to each segment. After landowner permission was obtained, six segments were selected on the Tenmile Creek mainstem between river kilometer (RK) 38 and 39.5 (river mile [RM] 23.6 and 24.5; sites 01 to 06) (figure 1) and two additional segments were chosen on a tributary joining Tenmile Creek at RK 38.2 (RM 23.7) that we named Eickholt Ditch (sites 07 and 08). Two segments were selected on Langenderfer Ditch (sites 09 and 10), a tributary to Prairie Ditch which, in turn, joins Tenmile Creek/Ottawa River at RK 24 (RM 14.9). Two final segments (sites 11 and 12) were selected on Prairie Ditch at RK 5 (RM 3.1).

Segments were selected in an interspersed manner such that no segment classified as $\mathrm{Ht}$ would be adjacent to another Ht segment. Sites were minimally $50 \mathrm{~m}$ (164 ft) apart, and all sampling occurred from the farthest downstream to the farthest upstream to leave each new segment undisturbed.

Classification of Morphology. The twelve stream segments were classified by visual inspection in the field as either $\mathrm{Ht}$ or $\mathrm{Ho}$ with six segments representing each category. Subsequently, we quantified their degree of heterogeneity by measuring the wetted widths of the channel (from water edge to water edge) at $2 \mathrm{~m}(6.6 \mathrm{ft})$ intervals over the segment's $20 \mathrm{~m}(66 \mathrm{ft})$ during base flow conditions and by calculating the coefficient of variation (CV) for these eleven width measurements (table 1). The mean CV for $\mathrm{Ht}$ segments was significantly greater ( $p$ $<0.001)$ than that of Ho stream segments $(0.22 \pm 0.07$ standard deviation [sd] and $0.08 \pm 0.04 \mathrm{sd}$, respectively). To quantify the variability in channel depth throughout each segment, we measured three channel depths (the channel midpoint and half way between the midpoint and each bank) at 4 $\mathrm{m}$ (13.2 ft) intervals along each $20 \mathrm{~m}$ (66 $\mathrm{ft}$ ) segment and calculated the $\mathrm{CV}$ among these 18 values (table 1 ). As with the width measurements, increasing values of the $\mathrm{CV}$ represented higher heterogeneity. The mean $\mathrm{CV}$ for these depth measurements was not significantly different $(p=0.21)$ between $\mathrm{Ht}$ and Ho stream segments $(0.27 \pm 0.08 \mathrm{sd}$ and $0.24 \pm 0.09 \mathrm{sd}$, respectively).

Environmental Conditions. All stream banks in our sites had steep slopes with vegetation dominated by reed canary grass (Phalaris arundinacea). Common submerged vegetation included patches of Elodea canadensis (Michx.), Rotala sp. and Eleocharis acicularis (L.). Many sites also had seasonally abundant patches of Cladophora sp. algae. Canopy cover was measured in the center of each stream using a convex forest crown densiometer (Spherical Model-A).

Environmental conditions were recorded during each sample event at the most upstream portion of each segment after the fish sampling had been completed. These data were collected to test the similarity of environmental conditions among segments during each of the eleven surveys we carried out in total during 2005 to 2006. Water temperature, $\mathrm{pH}$, dissolved oxygen, and conductivity were measured using PASCO Passport Explorer PS-2000 multimetric probes. Dissolved oxygen was measured on four sampling dates. Turbidity was measured using a modified Secchi disk similar to the LaMotte "Earth Force Elementary Education Watershed Field Trip Kit" \#5906. Discharge was estimated by measuring one cross section of the channel $\left(\mathrm{m}^{2}\right)$ and the flow of the water $\left(\mathrm{m} \mathrm{s}^{-1}\right)$ through that cross section using a neutrally buoyant object. Multiplying both measurements yielded water discharge $\left(\mathrm{m}^{3} \mathrm{~s}^{-1}\right)$.

Means of environmental data recorded per habitat type showed no significant difference between the two types of habitat during each sample event (table 2). Most sites lacked canopy cover.Three Ho sites, however, did have partial canopy cover, providing some shade for a portion of the day (Tenmile 02 [7.5\%], Tenmile 04 [68.5\%], and Eickholt 02 [49.0\%]).

Fish Sampling. Each segment was sampled thoroughly using two $3.7 \mathrm{~m}(12.1 \mathrm{ft})$ seines with $6 \mathrm{~mm}$ (0.25 in) mesh, starting at the farthest downstream site and working upstream (for example, from site 06 to 01 [figure 1]) to 
Table 2

Means ( \pm 1 standard deviation), temperature, $\mathrm{pH}$, dissolved oxygen, conductivity, turbidity, and discharge measurements recorded for all heterogeneous $(\mathrm{Ht})$ and homogenous $(\mathrm{Ho})$ segment classifications at each sample event from the Ottawa River, northwest Ohio, during eleven sample events between June 2005 and September 2006. An "-" value indicates no measurements recorded.

\begin{tabular}{|c|c|c|c|c|c|c|c|c|c|c|c|}
\hline $\begin{array}{l}\text { Environmental } \\
\text { data }\end{array}$ & \multicolumn{11}{|l|}{ Sample date } \\
\hline $\mathrm{Ht}$ & $25.6 \pm 1.1$ & $26.9 \pm 3.5$ & $23.8 \pm 4.1$ & $15.6 \pm 1.0$ & $1.4 \pm 0.2$ & $3.9 \pm 1.7$ & $16.1 \pm 3.1$ & $20.0 \pm 2.2$ & $25.4 \pm 2.6$ & $23.4 \pm 1.2$ & $16.6 \pm 1.5$ \\
\hline Ho & $24.7 \pm 1.3$ & $28.7 \pm 4.4$ & $26.9 \pm 2.8$ & $16.1 \pm 1.3$ & $1.0 \pm 0.2$ & $3.7 \pm 1.6$ & $15.0 \pm 3.2$ & $19.3 \pm 2.1$ & $24.6 \pm 2.4$ & $23.3 \pm 1.3$ & $15.9 \pm 1.1$ \\
\hline \multicolumn{12}{|l|}{$\overline{\mathrm{pH}}$} \\
\hline Ho & $7.7 \pm 0.3$ & $8.3 \pm 0.6$ & $9.4 \pm 0.5$ & $8.1 \pm 0.3$ & $8.2 \pm 0.2$ & $7.8 \pm 0.3$ & $8.4 \pm 0.1$ & $8.3 \pm 0.3$ & $8.1 \pm 0.2$ & $8.0 \pm 0.1$ & $8.1 \pm 0.2$ \\
\hline \multicolumn{12}{|c|}{ Dissolved oxygen (mg L-1) } \\
\hline $\mathrm{Ht}$ & $8.2 \pm 2.4$ & - & $10.6 \pm 4.7$ & - & - & - & - & $6.2 \pm 0.2$ & $5.1 \pm 0.4$ & - & - \\
\hline Ho & $7.0 \pm 1.1$ & - & $11.8 \pm 4.4$ & - & - & - & - & $5.9 \pm 0.2$ & $5.1 \pm 0.7$ & - & - \\
\hline \multicolumn{12}{|c|}{ Conductivity (mS cm${ }^{-1}$ ) } \\
\hline Ho & $50 \pm 17$ & $19 \pm 19$ & $37 \pm 38$ & $52 \pm 38$ & $67 \pm 46$ & $60 \pm 32$ & $60 \pm 34$ & $30 \pm 17$ & $75 \pm 43$ & $132 \pm 88$ & $73 \pm 37$ \\
\hline \multicolumn{12}{|c|}{ Discharge $\left(\mathrm{m}^{3} \mathrm{~s}^{-1}\right)$} \\
\hline $\mathrm{Ht}$ & $0.03 \pm 0.01$ & No flow & No flow & No flow & $0.13 \pm 0.06$ & $0.16 \pm 0.06$ & $0.09 \pm 0.06$ & $0.11 \pm 0.08$ & $0.08 \pm 0.01$ & $0.03 \pm 0.01$ & $0.04 \pm 0.02$ \\
\hline Ho & $0.02 \pm 0.01$ & No flow & No flow & No flow & $0.14 \pm 0.01$ & $0.12 \pm 0.06$ & $0.06 \pm 0.03$ & $0.10 \pm 0.04$ & $0.07 \pm 0.01$ & $0.02 \pm 0.01$ & $0.05 \pm 0.03$ \\
\hline
\end{tabular}

avoid disturbing unsampled segments. In each segment, one seine (stationary) was placed as a blockade at the downstream end, the second seine (sweep) was started upstream at the midpoint of the segment and was pushed downstream to the stationary seine, making a 90-degree pivot through the stationary seine to shore. The stationary seine was then turned on a 90-degree pivot through the lower end of the sample segment to capture any fish missed by the sweep seine. This technique is similar to the one described by Peterson et al. (2005). All fish were then identified by species in the field in accordance with identification characteristics in Fishes of Ohio (Trautman 1981), aged into common sizeage classes (adult, subadult, juvenile), assessed for spawning condition, and released downstream of the newly placed stationary seine at the midpoint of the segment. The procedure was repeated in the upstream portion of the segment to promote accurate sampling of the entire stretch. When needed, we photographed fish to double-check their identity with taxonomic keys.

At the conclusion of the project, we used this same sampling protocol to advance through a $105 \mathrm{~m}$ (345 ft) segment (figure 1) with mixed $\mathrm{Ht}$ and Ho habitat to calculate a formal IBI (Karr 1981). This would (1) allow comparison of our sample segments in the Ottawa River with other streams throughout Ohio, (2) test for saturation of the species-area curve for this stream segment, and (3) sample across a gradient of $\mathrm{Ht}$ and Ho habitats.

Data Analysis. Dependent variables calculated for each segment during individual sampling events included fish abundance per species, species richness, $\mathrm{H}^{\prime}$, number of feeding guilds, and a modified IBI. Our 20 m (66 $\mathrm{ft}$ ) segments are a subsample of the typical 100 to $200 \mathrm{~m}$ (328 to $656 \mathrm{ft}$ ) IBI assessment. Feeding guilds and the IBI were calculated according to the Ohio Environmental Protection Agency's "Biological Criteria for the Protection of Aquatic Life" (Ohio Environmental Protection Agency 2006). To analyze how fish community indices related to habitat and to allow us to control for errors correlated with time, we used repeated measures analysis of variance (ANOVA). The full model can be described as

Community metric $=$ Habitat + Time $+($ Habitat $\times$ Time).

We tested for correlated errors due to time (the independent factor "Time," e.g., the month and year of the sample) using a Null
Model Likelihood Test to test whether the model needed a covariance structure associated with correlated random effect errors in time (the null hypothesis was that errors were independently distributed). Upon rejecting the null hypothesis $(\alpha=0.05)$, the covariance models we tested were Topelitz, compound symmetry, autoregressive, and autoregressive with compound symmetry (Littell et al. 2006), in which the latter three models accounted for the unequally spaced intervals in time due to weather conditions (e.g., both flooded or frozen streams). We selected the covariance structure that minimized the values of three criteria to determine the best fit covariance model: Akaike's information criterion, a corrected version of AIC, and the Bayesian information criterion. Once we selected the most appropriate covariance structure, we tested Habitat effects (as an independent factor) using $F$-test criteria where the Kenward-Roger correction reduced Type I error (Littell et al. 2006). We used SAS 9.1 (SAS Institute Inc., Cary, North Carolina, United States) for analysis using the PROC MIXED procedure.

\section{Results and Discussion}

Abundances and Species Composition. A total of 10,843 fish representing 24 spe- 
Table 3

Summary of total catch, percent of total catch, total catch by habitat, percent of total catch by habitat, total catch young of year (YOY) by habitat, and total catch of apparent gravid females by habitat from the Ottawa River, northwest Ohio, during eleven sample events.

\begin{tabular}{|c|c|c|c|c|c|c|c|c|c|c|}
\hline Species & $\begin{array}{l}\text { Species } \\
\text { total }\end{array}$ & $\begin{array}{l}\text { Total } \\
\text { catch (\%) }\end{array}$ & Ht total & Ho total & $\begin{array}{l}\text { Ht } \\
\text { of total } \\
\text { catch (\%) }\end{array}$ & $\begin{array}{l}\text { Ho } \\
\text { of total } \\
\text { catch (\%) }\end{array}$ & Ht YOY & Ho YOY & $\begin{array}{l}\text { Ht } \\
\text { gravid }\end{array}$ & $\begin{array}{l}\text { Ho } \\
\text { gravid }\end{array}$ \\
\hline Pimephales promelas & 2,867 & 26.4 & 2,014 & 853 & 18.6 & 7.9 & 433 & 575 & 70 & 12 \\
\hline Etheostoma microperca & 1,514 & 14.0 & 1,109 & 405 & 10.2 & 3.7 & 10 & 15 & 44 & 40 \\
\hline Campostoma anomalum & 910 & 8.4 & 579 & 331 & 5.3 & 3.1 & 472 & 295 & 3 & 3 \\
\hline Semotilus atromaculatus & 510 & 4.7 & 364 & 146 & 3.4 & 1.3 & 242 & 80 & 5 & 5 \\
\hline Luxilus chrysocephalus & 513 & 4.7 & 321 & 192 & 3.0 & 1.8 & 241 & 174 & 2 & 0 \\
\hline Amerius natalis & 155 & 1.4 & 114 & 41 & 1.1 & 0.4 & 106 & 37 & 1 & 0 \\
\hline Lythrurus umbratilis & 105 & 1.0 & 75 & 30 & 0.7 & 0.3 & 31 & 16 & 11 & 7 \\
\hline Catostomus commersonii & 73 & 0.7 & 64 & 9 & 0.6 & 0.1 & 44 & 9 & 0 & 0 \\
\hline Carassius auratus & 44 & 0.4 & 33 & 11 & 0.3 & 0.1 & 15 & 9 & 0 & 0 \\
\hline Micropterus salmoides & 34 & 0.3 & 22 & 12 & 0.2 & 0.1 & 20 & 12 & 0 & 0 \\
\hline Cyprinus carpio & 20 & 0.2 & 20 & 0 & 0.2 & 0.0 & 20 & 0 & 0 & 0 \\
\hline Umbra limi & 35 & 0.3 & 17 & 18 & 0.2 & 0.2 & 10 & 14 & 0 & 0 \\
\hline Notemigonus crysoleucas & 11 & 0.1 & 10 & 1 & 0.1 & 0.0 & 3 & 0 & 0 & 0 \\
\hline Lepomis gibbosus & 9 & 0.1 & 9 & 0 & 0.1 & 0.0 & 0 & 0 & 0 & 0 \\
\hline Gambusia affinis & 10 & 0.1 & 5 & 5 & 0.0 & 0.0 & 1 & 3 & 0 & 0 \\
\hline Percina maculata & 4 & 0.0 & 4 & 0 & 0.0 & 0.0 & 0 & 0 & 1 & 0 \\
\hline Amerius melas & 1 & 0.0 & 1 & 0 & 0.0 & 0.0 & 0 & 0 & 1 & 0 \\
\hline Perca flavescens & 1 & 0.0 & 1 & 0 & 0.0 & 0.0 & 0 & 0 & 0 & 0 \\
\hline
\end{tabular}

Notes: $\mathrm{Ht}=$ heterogeneous channel segment classifications. $\mathrm{Ho}=$ homogenous channel segment classifications.

cies were captured, identified, and released in 11 sampling events between June 2005 and September 2006 (table 3). The samples were dominated by two cyprinid species, the fathead minnow (Pimephales promelas Rafinesque) and the bluntnose minnow (P. notatus Rafinesque), representing $26.4 \%$ and $24.2 \%$ of the total catch, respectively. Both species are listed as tolerant (Ohio Environmental Protection Agency 2006) and are described as two of the most tolerant species of habitat degradation in Ohio (Trautman 1981). The least darter (Etheostoma microperca Jordan \& Gilbert) was also prevalent, with $14 \%$ of the total catch of which $73 \%$ occurred in Ht segments. The abundance of E. microperca is of note since it is listed as a State Species of Concern in Ohio (Ohio Division of Wildlife 2003) and was undocumented in three Ohio Environmental Protection Agency sampling events on this stretch (Dennis Mishne, Ohio Environmental Protection Agency, personal communication 2008). Other well-repre- sented species included the central stoneroller minnow (Campostoma anomalum Rafinesque) at $8.4 \%$ of the total catch, johnny darter (E. nigrum Rafinesque) at $6.2 \%$, orangethroat darter (E. spectabile Agassiz) at 5.1\%, striped shiner (Luxilus chrysocephalus Rafinesque) at $4.7 \%$, and creek chub (Semotilus atromaculatus Mitchill) at $4.7 \%$. The creek chub is listed as tolerant. All other species in this group are listed as intermediately tolerant, including the State Species of Concern least darter.

Five species were found in the Ht segments that were absent from Ho segments (table 3 ). These species were poorly represented in the overall catch, represented by only 35 individuals $(0.3 \%$ of the total catch or $0.5 \%$ of the total Ht catch). Three of these species, the common carp (Cyprinus carpio L.), pumpkinseed sunfish (Lepomis gibbosus L.), and yellow perch (Perca flavescens Mitchill), were found only during the July and August 2006 samples. They are assumed to have been present as the result of upstream migration during a flood pulse in July 2006 and had not been documented in the previous five years of monitoring. The remaining two species, the blackside darter (Percina maculata Girard) and black bullhead (Ameiurus melas Rafinesque), appeared in the spring months. It is possible that these individuals were looking for appropriate spawning habitat in Ht segments, consistent with their life history patterns (Trautman 1981). Three exotic species, the common goldfish (Carassius auratus L.), common carp, and the mosquito fish (Gambusia affinis Baird \& Girard) were found but made up very little of the total catch (74 individuals or $0.7 \%$ of the total). The scarcity of exotics was remarkable, considering the prevalence of exotic species in other regional aquatic systems (Sharma and Jackson 2007).

Community Metrics. Community metrics for each sampling event by habitat type are summarized in table 4. We determined compound symmetry was the best error structure for the species richness and the $\mathrm{H}^{\prime}$ measurements (table 4). The best error structure for abundance, the number of feeding guilds and 
Table 4

Summary of community metrics during each sampling event by habitat type. Reported values are the mean of six sites per habitat type per sampling event $(n=6)$ with their error reported as standard deviation.

\begin{tabular}{|c|c|c|c|c|c|c|c|c|c|c|c|}
\hline \multirow{2}{*}{$\begin{array}{l}\text { Community } \\
\text { metric }\end{array}$} & \multicolumn{11}{|l|}{ Metric mean } \\
\hline & $6 / 12 / 05$ & $8 / 3 / 05$ & $9 / 8 / 05$ & $10 / 13 / 05$ & $12 / 3 / 05$ & $3 / 23 / 06$ & $4 / 28 / 06$ & $6 / 5 / 06$ & $7 / 10 / 06$ & $8 / 13 / 06$ & $9 / 25 / 06$ \\
\hline Feeding guilds Ht & $2.5 \pm 1.5$ & $3.2 \pm 1.2$ & $3.0 \pm 0.6$ & $2.8 \pm 1.3$ & $2.7 \pm 2.3$ & $2.0 \pm 1.7$ & $3.7 \pm 0.5$ & $3.7 \pm 0.5$ & $3.7 \pm 0.5$ & $4.2 \pm 0.5$ & $3.8 \pm 0.5$ \\
\hline Feeding guilds $\mathrm{H}_{0}$ & $2.0 \pm 1.1$ & $2.5 \pm 1.4$ & $1.0 \pm 1.1$ & $1.3 \pm 1.0$ & $1.7 \pm 1.9$ & $1.3 \pm 1.0$ & $2.0 \pm 1.1$ & $2.8 \pm 0.8$ & $3.8 \pm 0.4$ & $3.0 \pm 1.0$ & $2.4 \pm 0.9$ \\
\hline Shannon diversity $\left(\mathrm{H}^{\prime}\right) \mathrm{Ht}$ & $1.04 \pm 0.6$ & $1.26 \pm 0.58$ & $1.16 \pm 0.23$ & $0.92 \pm 0.53$ & $0.81 \pm 0.66$ & $1.03 \pm 0.85$ & $1.47 \pm 0.25$ & $1.54 \pm 0.18$ & $1.94 \pm 0.14$ & $2.07 \pm 0.14$ & $1.50 \pm 0.50$ \\
\hline Shannon diversity $\left(\mathrm{H}^{\prime}\right) \mathrm{Ho}_{0}$ & $0.68 \pm 0.4$ & $1.02 \pm 0.60$ & $0.41 \pm 0.52$ & $0.49 \pm 0.41$ & $0.72 \pm 0.78$ & $0.57 \pm 0.56$ & $0.81 \pm 0.48$ & $0.98 \pm 0.39$ & $1.83 \pm 0.43$ & $1.17 \pm 0.60$ & $1.34 \pm 0.34$ \\
\hline Richness $\mathrm{Ht}$ & $5.5 \pm 3.1$ & $6.3 \pm 2.9$ & $5.0 \pm 1.9$ & $4.3 \pm 2.4$ & $4.0 \pm 3.8$ & $4.3 \pm 3.7$ & $6.8 \pm 1.0$ & $7.0 \pm 0.6$ & $9.8 \pm 1.5$ & $10.8 \pm 1.3$ & $8.6 \pm 2.1$ \\
\hline Richness Ho & $2.8 \pm 1.5$ & $5.2 \pm 2.8$ & $1.3 \pm 1.8$ & $2.2 \pm 2.0$ & $3.0 \pm 3.3$ & $2.2 \pm 1.8$ & $3.5 \pm 2.3$ & $5.3 \pm 2.3$ & $8.7 \pm 1.8$ & $6.2 \pm 2.9$ & $5.8 \pm 2.4$ \\
\hline $\mathrm{IBI} H \mathrm{Ht}$ & $20.7 \pm 3.2$ & $21.0 \pm 6.1$ & $19.0 \pm 1.3$ & $18.3 \pm 5.0$ & $20.3 \pm 8.1$ & $19.7 \pm 6.7$ & $20.7 \pm 2.3$ & $22.0 \pm 4.9$ & $27.3 \pm 5.1$ & $27.8 \pm 3.0$ & $22.6 \pm 4.6$ \\
\hline$|\mathrm{B}| \mathrm{H}_{0}$ & $19.3 \pm 2.8$ & $19.7 \pm 4.8$ & $16.3 \pm 3.7$ & $23.0 \pm 9.1$ & $17.7 \pm 5.2$ & $17.3 \pm 5.3$ & $20.7 \pm 8.3$ & $24.7 \pm 3.7$ & $24.7 \pm 3.4$ & $25.4 \pm 5.6$ & $23.4 \pm 4.3$ \\
\hline Abundance $\mathrm{Ht}$ & $78.0 \pm 63.5$ & $48.0 \pm 51.0$ & $99.0 \pm 87.9$ & $61.5 \pm 75.4$ & $34.3 \pm 40.7$ & $28.3 \pm 27.5$ & $84.8 \pm 91.2$ & $108.8 \pm 81.2$ & $135.2 \pm 100.2$ & $262.8 \pm 210.8$ & $433.2 \pm 413.5$ \\
\hline Abundance $\mathrm{Ho}_{0}$ & $27.0 \pm 26.2$ & $64.0 \pm 76.7$ & $16.7 \pm 29.3$ & $20.8 \pm 27.7$ & $12.7 \pm 13.3$ & $5.7 \pm 6.1$ & $22.0 \pm 26.9$ & $105.8 \pm 150.9$ & $94.3 \pm 66.9$ & $141.0 \pm 147.0$ & $65.0 \pm 64.3$ \\
\hline
\end{tabular}

Notes: $\mathrm{Ht}=$ heterogeneous channel segment classifications. $\mathrm{Ho}=$ homogenous channel segment classifications. IBI = Index of Biological Integrity.

\section{Table 5}

Summary of community metric statistics in a repeated measures analysis of variance.

\begin{tabular}{lllll}
\hline Metric & Error structure & Habitat & Time & Habitat $\times$ Time \\
\hline Abundance & Autoregressive & $F(1,8.21)=1.33, p=0.28$ & $F(10,86.2)=2.26, p=0.02$ & $F(10,86.2)=3.22, p=0.002$ \\
Richness & Compound symmetry & $F(1,10)=7.23, p=0.02$ & $F(10,96.1)=14.26, p=0.0001$ & $F(10,96.1)=0.95, p=0.49$ \\
$\mathrm{H}^{\prime}$ & Compound symmetry & $F(1,9.97)=6.50, p=0.03$ & $F(10,96.1)=9.33, p=0.0001$ & $F(10,96.1)=1.07, p=0.39$ \\
Feeding guilds & Autoregressive & $F(1,24.2)=12.96, p=0.01$ & $F(10,89.2)=3.34, p=0.001$ & $F(10,89.2)=1.06, p=0.34$ \\
IBI & Autoregressive & $F(1,10)=0.13, p=0.75$ & $F(10,96)=2.49, p=0.01$ & $F(10,96)=1.25, p=0.27$ \\
\hline
\end{tabular}

Notes: $\mathrm{H}^{\prime}=$ Shannon diversity. $\mathrm{IBI}=$ Index of Biological Integrity.

the IBI measurements was autoregressive with compound symmetry. Using our covariance models (table 5 ), we found that Time had a highly significant effect $(p<0.002)$ for all metrics, providing more evidence that we needed to control for Time effects to better interpret Habitat effects. That is, controlling for Time allowed us to partition variance due to Time from unexplained variance and thus would help us understand the significance of the variance explained by Habitat. The combined effect of Habitat $\times$ Time was highly significant for abundance $(p=0.002)$ but not for any of the other metrics. Thus, we could interpret any significant effects of Habitat without concern for Time for all measurements except abundance.

Habitat, our focal effect, had a significant impact on species richness $(p=0.02), \mathrm{H}^{\prime}$ $(p=0.03)$, and feeding guilds $(p=0.01)$. Estimates were higher for richness $(\mathrm{Ht}=$ $6.56 \pm 0.63 \mathrm{se}, \mathrm{Ho}=4.17 \pm 0.63 \mathrm{se}), \mathrm{H}^{\prime}$ $(\mathrm{Ht}=1.33 \pm 0.12 \mathrm{se}, \mathrm{Ho}=0.90 \pm 0.12 \mathrm{se})$, and total feeding guilds $(\mathrm{Ht}=3.2 \pm 0.20 \mathrm{se}$, $\mathrm{Ho}=2.2 \pm 0.20 \mathrm{se}$ ) (figure 2). Abundance and the IBI showed no significant effect for Habitat ( $p=0.28$ and 0.75 , respectively).
The significant differences in the variable of Time in our statistical model were likely exacerbated by the high variability in total rainfall between the two summers (May to September) included in this study. The summer of 2005 was somewhat dry with rainfall from May through September totaling only $33.8 \mathrm{~cm}$ (13.3 in). Average rainfall during those months is $40.0 \mathrm{~cm}$ (15.8 in) based on the nearby National Climatic Data Center station at Toledo Express Airport. As a result, no-flow conditions were commonly encountered during 2005 (table 2) and in September 2005 , four of the six Ho sites were dry, while none of the Ht sites went dry. In contrast,

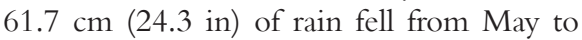
September in 2006, and September 2006 followed the wettest July on record for the Toledo area. This may have contributed to the highest fish abundances in both habitat types. Moreover, preceding this wet July, an intense storm on June 21, 2006, dropped $7.3 \mathrm{~cm}$ (2.9 in) in the area in only a few hours. This storm produced unusual floodplain streams that flanked, for a 10-day period, the last remaining dam on the Ottawa River, some $13 \mathrm{~km}$ (8.1 mi) downstream of our most down- stream site. Typically, this dam is a barrier for fish species migrating upstream from Lake Erie (Roberts et al. 2007). Consequently, in July and August of 2006, we seined species in our sample segments that we rarely recorded previously in monitoring of the Ottawa watershed upstream of the dam over the last five years (Crail, unpublished data). For example, adult bluegill sunfish (Lepomis macrochirus Rafinesque), pumpkinseed sunfish, largemouth bass (Micropterus salmoides Lacepede), and yellow perch were relatively abundant during the August 2006 sample at Langenderfer and Prairie ditches. Typically these species are encountered only as juveniles in these parts of the system, if they are encountered at all.

Reference Reach Index of Biological Integrity Score. 3,967 individuals representing 11 species were captured in the $105 \mathrm{~m}$ (345 ft) segment we sampled to quantify an IBI score. The IBI computed from these data yielded a score of 29, which classifies as "Fair" for a Huron Erie Lake Plain headwater stream in the Revised 2006 Ohio IBI scoring. Modified warmwater streams listed as "Fair" have an IBI between 28 and 


\section{Figure 2}

Estimates of species richness, Shannon diversity ( $\left.\mathrm{H}^{\prime}\right)$, and total feeding guilds in repeated measures analysis of variance. Closed and open bars represent heterogeneous ( $\mathrm{Ht}$ ) and homogeneous (Ho) segments, respectively. Reported error is standard error.

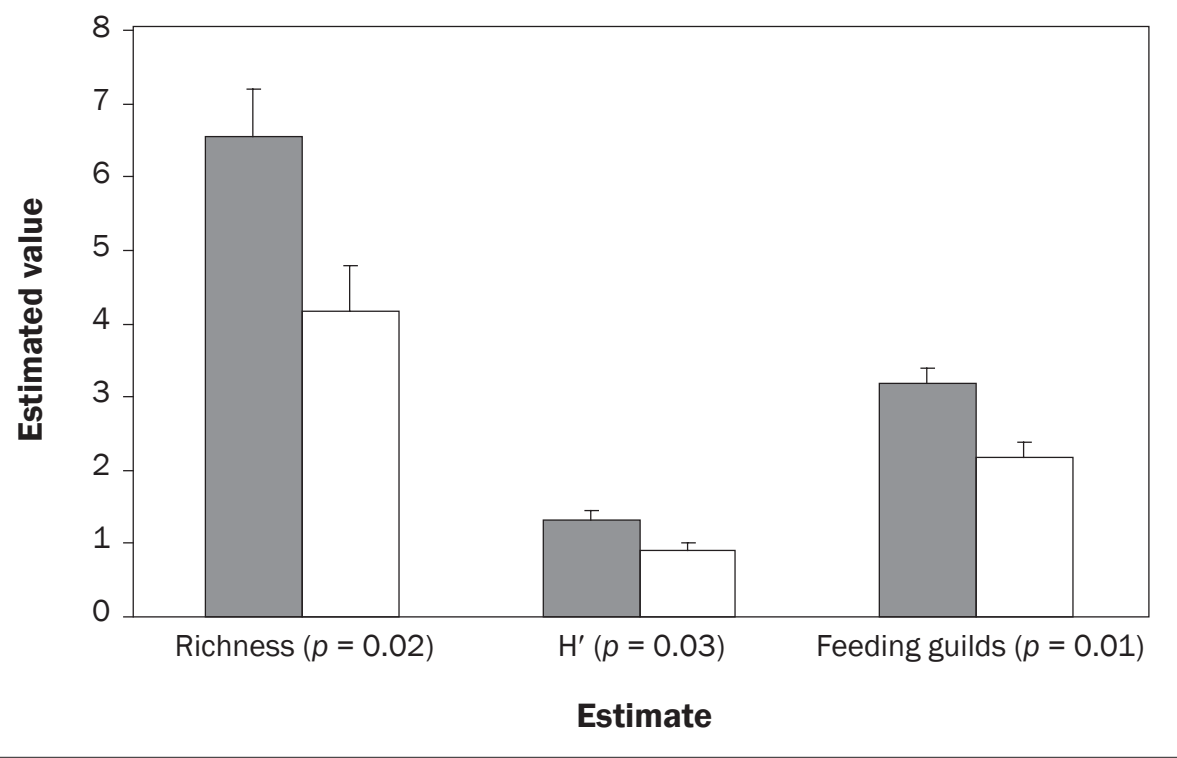

33 compared with "Poor" (12-27), "Good" (34-45) and "Exceptional" (46-60) (Ohio Environmental Protection Agency 2006). Only one exotic individual (a goldfish) was captured during the event. This score was greater than the highest mean monthly score for the modified IBI estimated by the model (table 4).

\section{Summary and Conclusions}

We found evidence that initial development of habitat heterogeneity within dredged agricultural headwater streams showed significant increases in fish assemblage measurements of richness, diversity, and feeding guilds. In spite of decades of continual disturbance by humans to improve drainage, the channelized and entrenched headwaters of the Ottawa River possess a fish assemblage that ranks "Fair" in comparison to statewide IBI assessments of streams. Although dominated by two tolerant species, the habitat is suitable for a large population of the least darter, a State Species of Concern, in addition to twenty other native species of fish. While present, three exotic species accounted for only a very small proportion of the fish assemblage.

Our understanding of the specific relationship between fish assemblage and compound channels with vegetated benches is only now developing, as papers such as Stammler et al. (2008), Smiley et al. (2008), and King et al. (2008) emerge from studies that examine fish community response to these in-chan- nel habitats. These findings match the notion in community ecology, both within aquatic systems (e.g., Angermeier and Schlosser 1989) and beyond (e.g., Rosenzweig 2002), that habitat heterogeneity may substitute for geographic area with regard to species richness and diversity in species-area curves. Furthermore, Lyons et al. (2000) and Rhoads et al. (2003) establish a new pattern of thinking about riparian vegetation and the contribution of herbaceous vegetation (particularly grasses) to habitat heterogeneity in smaller order streams. This certainly deserves further study.

Our reference reach IBI sample demonstrates that the upper Ottawa River is a compromised system in comparison with other Ohio streams. It also demonstrates that our sample IBI scores were somewhat suppressed in richness in comparison to the reference reach IBI sample. This is most likely related to the length of sample, which was $1 / 5$ th to $1 / 10$ th of the sample length of the traditionally run IBI sample, thus demonstrating our $20 \mathrm{~m}$ (66 ft) segments had not reached saturation of species area. While we expected to see a significant difference in the IBI scores between the two habitat types, we find the similarity of IBI scores between habitats consistent with the purpose of the index, namely to compare an entire modified stream to an unmodified stream and detect gradations between these definitions. In essence, the IBI succeeds in comparing the fish community of the upper Ottawa River watershed against streams statewide in a qualitative manner, as it was designed to do (Karr 1981).

In our study, stream heterogeneity was promoted by the presence of a tolerant grass species, Phalaris arundinacea. During a prolonged flood in July 2006, we observed death and shearing of the vegetated Phalaris benches outside of our sampled segments. Future work may test the effect of native stream bank vegetation, such as the various cordgrasses (Spartina spp.) and forbs such as Iris sp., Lobelia sp., and Rudbeckia sp., all of which were found in low densities in our sites. Encouraging establishment of these species may have benefits for the development of Ht stream habitat in these lotic systems. This, in turn, promotes a more rich and diverse fish community within these drainage ditches. We speculate that continued success in soil conservation in the midwestern United States may reduce the frequency of dredging in agricultural streams, promote the development of Ht channel features, and benefit stream fish communities that rely on headwater habitat.

\section{Acknowledgements}

This research was sponsored by the Ohio Lake Erie Protection Fund (251-05) and the University of Toledo, Department of Environmental Sciences. Numerous undergraduate and graduate students assisted in the field. Dr. Elliot Tramer and Dr. James Martin-Hayden provided helpful comments on initial drafts, and landowners in the region graciously provided access to field sites to make this work possible. Recommendations by three anonymous reviewers greatly improved our paper.

\section{References}

Angermeier, P.L., and I.J. Schlosser. 1989. Species-area relationships for stream fishes. Ecology 70:1450-1462.

Benedict, M., and J.F. Gottgens. 2006. Riparian Forests in NW Ohio Watersheds: Relations Between Landscape Structure, Land Use, and Water Quality in Regional Rivers. Final Report to the Ohio Lake Erie Commission (Grant: SG 251-05). Toledo, OH.

Boody, G., B.Vondracek, D.A. Anodow, M. Krinke, J. Westra, J. Zimmerman, and P. Welle. 2005. Multifunctional Agriculture in the United States. BioScience 55:27-38. Frothingham, K.M., B.L. Rhoads, and E.E. Herricks. 2002. A multiscale conceptual framework for integrated ecogeomorphological research to support stream naturalization in the agricultural Midwest. Environmental Management 29:16-33.

Karr, J.R. 1981. Assessment of biotic integrity using fish communities. Fisheries 6(6):21-27. 
King, K.W., P.C. Smiley, B.J. Baker, and N.R. Fausey. 2008. Validation of paired watersheds for assessing conservation practices in the Upper Big Walnut Creek watershed, Ohio. Journal of Soil and Water Conservation 63(6):380-395, doi:10.2489/jswc.63.6.380.

Landwehr, K., and B.L. Rhoads. 2003. Depositional response of a headwater stream to channelization, east central Illinois, USA. River Research and Applications 19:77-100.

Littell, R.C., G.A. Milliken, W.W. Stroup, R.D.Wolfinger, and O. Schabenberger. 2006. SAS for Mixed Models, Second Edition. Cary, NC: SAS Institute Inc.

Lyons, J., S.W. Trimble, and L.K. Paine. 2000. Grass versus trees: Managing riparian areas to benefit streams of central North America. Journal of the American Water Resources Association 36:919-930.

Meyer, J.L., D.L. Strayer, J.B. Wallace, S.L. Eggert, G.S. Helfman, and N.E. Leonard. 2007. The contribution of headwater streams to biodiversity in river networks. Journal of the American Water Resources Association 43:86-103.

Ohio Division of Wildlife. 2003. Wildlife that are considered Endangered, Threatened, Species of Concern, Special Interest, Extirpated, or Extinct in Ohio. Columbus, OH. http://www.dnr.state. oh.us/Home/ExperienceWildlifeSubHomePage/ Endangeredthreatenedspeciesplaceholder/ resourcesmgtplansspecieslist/tabid/5664/Default.aspx.

Ohio Environmental Protection Agency. 2006. Biological criteria for the protection of aquatic life. Columbus, OH. http://www.epa.ohio.gov/dsw/bioassess/ BioCriteriaProtAqLife.aspx.

Peterson, J.T., N.P. Banish, and R.F. Thurow. 2005. Are block nets necessary? Movement of stream-dwelling salmonids in response to three common survey methods. North American Journal of Fisheries Management 25:732-743.

Rhoads, B.L., J.S. Schwartz, and S. Porter. 2003. Stream geomorphology, bank vegetation, and three-dimensional habitat hydraulics for fish in midwestern agricultural streams. Water Resources Research 39:1218.

Roberts, S.J., J.F. Gottgens, A.L. Spongberg, J.E. Evans, and N.S. Levine. 2007. An Integrated approach to assessing potential dam removals: An example from the Ottawa River, NW Ohio. Environmental Management 39(1):113-124.

Rosenzweig, M.L. 2002. Species Diversity in Space and Time. Sixth Edition. Cambridge, United Kingdom: Cambridge University Press.

Schlosser, I.J. 1995. Critical landscape attributes that influence fish population dynamics in headwater streams. Hydrobiologia 303:71-81.

Sharma, S., and D.A. Jackson. 2007. Fish assemblages and environmental conditions in the lower reaches of northeastern Lake Erie tributaries. Journal of Great Lakes Research 33:15-27.
Smiley, P.C., R.B. Gillespie, K.W. King, and C. Huang. 2008. Contribution of habitat and water quality to the integrity of fish communities in agricultural drainage ditches. Journal of Soil and Water Conservation 63(6):218A-219A, doi:10.2489/jswc.63.6.218A.

Stammler, K.L., R.L. McLaughlin, and N.E. Mandrak. 2008. Streams modified for drainage provide fish habitat in agricultural areas. Canadian Journal of Fisheries and Aquatic Sciences 65:509-522.

Trautman, M.B. 1981. The Fishes of Ohio. Second Edition. Columbus, $\mathrm{OH}$ : Ohio State University Press.

USEPA (US Environmental Protection Agency. 2009. Great Lakes Area of Concerns. Maumee Area of Concern. http://www.epa.gov/glnpo/aoc/maumee.html.

Ward,A.D., and S. W.Trimble. 2004. Environmental Hydrology. Second Edition. Boca Raton, FL: CRC Press. 